\title{
World Environment Day Speech* by President of Brazil
}

I feel deeply honoured at being given the opportunity to participate in the commemorations of World Environment Day in the same city where, nineteen years ago, the historic United Nations Conference on the Human Environment was held. On this day only a year ago, I travelled to the Pantanal marshlands of Mato Grosso in Brazil, to make a public statement of my Government's stand regarding the relation between Man and Nature - a stand I would now like to share with such a distinguished audience.

Since that pioneering 1972 Conference, Mankind has become more acutely aware that its future is inseparably linked to the protection of the natural environment in which we live. At that time, the physical and biological equilibrium that supports the complex 'global ecosystem' - a chain in which interminable links, many of which have been insufficiently analysed or are even unknown to science, ensure the continuity of life on our planet - was not as delicate as it is today.

Few then made hard-and-fast statements about the binding links between economic prosperity and a commitment to environmental preservation. It was still reckoned that progress would bring the solution to all ills. Recent events have demonstrated the fallacy of this conception.

\section{Dangers of Disorderly Growth}

Unbridled, disorderly growth - achieved at any cost — waste, and an excessively consumistic approach, have clearly aggravated the problems which Man has sought to solve as much as the tragic poverty that is perpetuated in the 'developing' world.

Today it is clear that growth, divested of concern for its effects on the environment, results in an undermining of the objectives which it aims to fulfil, placing the target of development coupled with social welfare at an ever-greater distance.

It is not a matter of spurning the objectives of well-being propitiated by material advancement, laudable though they are in themselves; rather, it is a matter of rethinking the very notion of progress - a progress that is not reduced to the mere enumeration of growth statistics but that implies, besides improvement of social indicators, real and effective concern for environmental protection.

\section{Prosperity Only with Due Environmental Concern}

Future prosperity can only be secured by the necessary balance between development and Nature conservation. Underdevelopment is a source of environmental degradation: one cannot seek to protect the environment without raising the standards of living of the vast majority of the world's human population.

There is one year to go before the opening of the United Nations Conference on Environment and Development, which my country is honoured to be able to host in Rio de Janeiro. A necessary synthesis of the equation between the environment and development, the agenda for the Conference weaves a close-knit, intrinsic relation between issues of a multiple nature.

Rio-92 will lay the foundations for a more even-handed and environmentally sustainable ordering of the world economy than currently prevails. Brazil's expectations are by no means moderate; to our mind the Conference represents an endeavour on the part of the international community to foster development by securing access to environmentally healthy technologies on non-commercial terms.

\section{World-wide Actions Needed for Success}

It will be up to the world's States to affirm this political disposition and determination by establishing basic legal and other instruments and providing circumstances that will enable private enterprise to undertake the necessary transfer of technology and other aspects required for success. We are similarly aware that reversing the present tendency towards environmental degradation on a global scale will require hefty outlays.

The allocation of new and additional financial flows, with no strings attached, that will need to be forthcoming for the funding of undertakings in the environmental sphere, must not imply detrimental channelling of essential resources away from economic development programmes. Despite the dimensions of the challenges which we face, Brazil is optimistic about the prospects for Rio-92; and we have striven to devote our best endeavours to creating optimum conditions for welcoming delegates from all the corners of the Earth.

\footnotetext{
* Delivered in Portuguese in the Grand Hotel, Stockholm, Sweden, on 5 June 1991, in conjunction with the presentation of emblems and certificates, respectively, by the Executive Director of UNEP and HM The King of Sweden, of the Global 500 Roll of Honour, and the International Sasakawa Environment Prize, together with other activities marking World Environment Day. — Ed.
} 
Here in Stockholm we have been able to prepare the ground for industrialized countries to enter the postindustrial age and to obtain the capacity for developing the technologies and acquiring the resources that are needed for promoting healthier development.

Mankind must not fail to grasp the opportunity of erecting the pillars of sustainable, egalitarian development for all nations in Rio de Janeiro in 1992, so as to safeguard and secure the Earth's future.

FERNANDO COLLOR

President of the Federative Republic of Brazil

Office of the President

Brasilia

Brazil.

\section{EDITORIAL COMMENT}

\section{UNCED 1992 and its Need of a Mountain Agenda}

$\mathrm{T}$ he United Nations Conference on Environment and Development (UNCED) will open on 1 June 1992 in Rio de Janeiro, Brazil, just 20 years after its predecessor, the landmark 'Stockholm Conference' (officially styled the United Nations Conference on the Human Environment) of 1972 helped to put environment on the world's political agenda. Interestingly, the Secretary-General for 1992 is the same man who propelled the Stockholm Conference to such overall success, Maurice F. Strong, of Canada.

Now, as then, there is a rush for influence. There is also a widespread apprehension that anything missing from the Conference agenda will be at a disadvantage in the years to come. The ambitions of the Conference are not modest; the principles which bear on environmental and developmental concerns are grouped in the so-called Earth Charter, and the assembly of action resolutions is referred to as the planetary management agenda for the next century, or Agenda 21 .

The Stockholm Conference necessarily chose to highlight the more pressing concerns of the time. Mountain ecosystems did not feature, nor did acid rain, stratospheric ozone*, or climatic change. Indeed $^{*}$ the concept of planetary management was regarded then in political circles as hardly serious. The twenty years which have passed since Stockholm have changed all that.

\section{Mountain Aspects}

Why should mountain ecocomplexes and their component ecosystems feature at Rio? Rather in the manner of the above-mentioned trio - acid rain, stratospheric ozone, and climatic change - at the time of Stockholm, mountain ecosystems were already known to some people to be a source of urgent concern. For they were rapidly becoming degraded under pressure from growing human populations and their various demands. The intervening years have made these fears and their outcomes more and more obvious and serious.

Montane ecosystems cover some $20 \%$ of the Earth's land surface and directly provide the life-support base for about $10 \%$ of the global human population. Indirectly, mountains are a source of water and energy, timber and minerals, spiritual inspiration and recreation, for more than half the world's population.

The people whose life-support base is in mountain regions amount to nearly 500 millions. They are mostly poor, subject to high population-growth, and politically marginal; yet they are the stewards of regions whose degradation will adversely affect the conditions of life of three to four times as many people on the plains below.

\section{Storehouse of Biodiversity}

Mountain are the storehouse of a great wealth of biodiversity; they also shelter a greater treasure of cultural diversity, together with associated indigenous environmental knowledge, than any other major physiographic division. These two characteristics are the direct consequences of the extreme range of

\footnotetext{
* Discussed in some detail already in our first International Conference on Environmental Future (1st ICEF) held in Finland a full 'year before Stockholm'. - Ed.

$\uparrow$ Already adumbrated, together with the need of a holistic viewpoint and treatment, in our 1st ICEF. — Ed.
} 